\title{
Resilience of prickly burnet to management in east Mediterranean rangelands
}

\author{
A. PEREVOLOTSKY, G. NE'EMAN, R. YONATAN, AND Z. HENKIN
}

Authors are research scientist (A.P.) and field technician (R.Y.) with the Dept. of Natural Resources, Agricultural Research Organization-The Volcani Center, P.O. Box 6, Bet Dagan 50250, Israel; Senior teacher (G.N.), Dept. of Biology, University of Haifa at Oranim, Tivon 36006, Israel; and research scientist (Z.H.), Galilee Technological Center (MIGAL), Qiryat Shemona, Israel.

\begin{abstract}
Large areas of rangelands in the east Mediterranean Basin are dominated by dense cover of the unpalatable, dwarf shrub prickly burnet (Sarcopoterium spinosum (L.) Spach.). This study examined the effectiveness of various shrub control treatments (mechanical removal, chemical/2,4-D control, prescribed burning), combined with NPK fertilization, to reduce shrub cover and encourage the growth of palatable herbaceous vegetation. Chemical control was the most effective treatment, reducing prickly burnet cover to $40 \%$ of the initial level 2 years after treatment. Mechanical removal maintained shrub cover at $60 \%$ of the initial level, whereas the effect of fire was not detectable after 2 years. Annual and perennial herbaceous vegetation cover was negatively correlated with shrub cover. Fertilization had no effect on the cover of the vegetative components, but increased biomass on the herbaceous patches by $25-240 \%$, depending on the treatment. Our results demonstrate the exceptionally high resilience of prickly burnet growing on chalk substrate to disturbance or attempted eradication, thus rendering most of the tested management options highly ineffective. Effective improvement of rangeland dominated by prickly burnet requires, most probably, a combined treatment including removal of mature shrubs, suppressing their recovery, and stimulating the competing grass component.
\end{abstract}

Key Words: Shrub encroachment, Mediterranean ecosystem, fertilization, fire, range improvement, Sarcopoterium spinosum

The relationships between woody and herbaceous vegetation are of foremost significance for free-ranging livestock. In most cases, woody vegetation provides a limited contribution to the livestock diet whereas it may dominate the space available for forage plants. Concomitantly, herbaceous vegetation, the most significant diet component for herbivores, may be replaced by woody species.

Human intervention such as shrub removal, aimed at decreasing woody cover while increasing herbaceous yield, began in the Mediterranean region in historic times (Naveh and Dan 1973) and has continued ever since (Passera et al. 1992).

The authors wish to thank The Israeli Range Management Advisory Board for financial support. Dr. No'am Seligman, 2 anonymous reviewers and the Journal of Range Management Associate Editor provided helpful comments on an earlier version of the manuscript.

Contribution from the Agricultural Research Organization-The Volcani Center Bet Dagan, Israel, No. 2039-E, 1996 series.

Mansucript accepted 17 Nov. 00

\section{Resumen}

Grandes áreas de pastizal del este de la cuenca del Mediterráneo están dominados por una cubierta densa del arbusto enano y no apetecido "Prickly burnet" (Sarcopoterium spinosum (L.) Spach.). Este estudio examina la efectividad de varios tratamientos de control de arbustos (remoción mecánica, control químico/ con 2,4-D y fuego prescrito) combinados con fertilización de NPK para reducir la cobertura del arbusto y promover el crecimiento de la vegetación herbácea apetecible. El control químico fue el tratamiento más efectivo, después de dos años de tratamiento la cobertura de "Prickly burnet" estaba reducida a un $\mathbf{4 0 \%}$ de la cobertura inicial. La remoción mecánica mantuvo la cobertura del arbusto en un $60 \%$ del nivel inicial, mientras que el efecto del fuego no fue detectable después de dos años. La vegetación herbácea anual y perenne se correlaciono negativamente con la cobertura del arbusto. La fertilización no tuvo efecto en la cobertura de los componentes vegetativos, pero incremento la biomasa de los parches de vegetación herbácea, el aumento de biomasa varió de 25 a $250 \%$ dependiendo del tratamiento. Nuestros resultados demuestran la capacidad de recuperación excepcionalmente alta del "Prickly burnet" al disturbio o intento de erradicación, convirtiendo en inefectivas a la mayoría de las opciones de manejo evaluadas. El mejoramiento efectivo del pastizal dominado por "Prickly burnet" requiere , muy probablemente, de un tratamiento combinado incluyendo la remoción de arbustos maduros, suprimiendo su recuperación y estimulando el componente de zacates competitivos.

Continuous severe exploitation of the evergreen dense maquis, which prevails in the Mediterranean Basin, caused its degradation to a dwarf shrub formation known in Israel as batha and in Greece as phrygana. The dominant species in these communities in the east Mediterranean is the thorny and unpalatable dwarf shrub prickly burnet (Sarcopoterium spinosum (L.) Spach.). Prickly burnet is a common invader of abandoned cropland (Litav and Orshan 1971). According to pollen records, prickly burnet was present in northern Israel as early as the 3rd century A.D. (Baruch 1986). In many cases, the prickly burnet community comprises a long-standing, sustainable pioneering stage (Zohary 1962).

Range improvement within the context of Mediterranean ecosystems primarily means preventing woody vegetation from replacing the herbaceous vegetation - the main source of palatable forage. Such management, in fact, opposes the natural trend of succession in most Mediterranean ecosystems and, therefore, requires active intervention. As a result, Mediterranean grass- 
lands are, in a sense, a 'successional anticlimax'; the term itself is something of an oxymoron (Seligman 1996).

The working hypothesis in this study was that under existing conditions, management treatments can establish a new balance between dwarf shrubs and herbaceous vegetation. Specifically, we wanted to determine the feasibility of improving chalk rangelands through shrub removal by mechanical means, selective herbicide application, or controlled burning while enhancing growth of herbaceous vegetation by fertilizer application. The assumption behind the research was that the combined effect of shrub control and nutrient amelioration can create a stable grassland community.

\section{Materials and Methods}

\section{Experimental Site}

The experimental site is located in northern Israel, in the hills of the lower Galilee, $15 \mathrm{~km}$ east of Haifa and the Mediterranean coast $\left(32^{\circ} 43^{\prime} \mathrm{N} 35^{\circ} 06^{\prime} \mathrm{E}\right)$. The site is situated on the upper part of a $5 \%$ south-facing slope, at $100 \mathrm{~m}$ above sea level. The climate is semi- humid Mediterranean; mean annual rainfall is $600 \mathrm{~mm}$ (ranging from 400 to 700), occurring mostly during winter $(90 \%$ in December-February). Average annual temperature is $19^{\circ} \mathrm{C}$ (Average December temp. is $10^{\circ} \mathrm{C}$, August $28^{\circ} \mathrm{C}$ ). The bedrock is Eocenian chalk, covered by dark grey Rendzina (Haploxerolls) soil (Dan et al. 1962).

Vegetation is dominated by $S$. Spinosum (L.) Spach, with other woody species and vines, remnants of vallonea oak (Quercus ithaburensis Decaisne) savanna that covered the region in historical times. Dominant perennial grasses at the site are
Dactylis glomerata L. and Andropogon distachyus. L. Among annual grasses, Avena sterilis is the most common.

\section{Experimental Design}

Forty, 5 x $5 \mathrm{~m}$ plots, with a separating buffer zone of $0.5 \mathrm{~m}$, were established in a relatively homogeneous area. The experimental site was fenced against human or livestock disturbance in autumn of 1989. The experimental design included 2 levels, the first consisting of 4 shrub removal treatments: 1) control; 2) shrub removal by manual means with minimal soil disturbance; 3) herbicide spraying with 5 liter $\mathrm{ha}^{-1}$ of 2,4-D applied as a $2 \%$ solution in 50 liter of water; and 4) controlled burning of the shrub canopies.

Shrub removal was implemented during autumn (November 1989). 'Shrub removal' involved hoeing-off the aboveground parts of the S. spinosum and removal of the material from the experimental site. Herbicide spraying was implemented in mid- winter of the first year (January 1990). Herbicide was applied from a back sprayer as a foliage wetting spray covering all of the plant green parts until the spray dripped off. The herbicide, 2,4-D, effectively kills mature prickly burnet shrubs and is frequently used for dwarf shrub control on rangelands in Israel (e.g. Seligman and Katzir 1965, Gutman et al. 1990). Controlled burning was very localized, conducted by spraying each shrub individually with fuel from a back sprayer and igniting it. Under these conditions, fire had very little impact on the surrounding vegetation.

The second experimental level was application of $50 \mathrm{~kg} \mathrm{ha}^{-1}$ of a composite fertilizer $(20 \mathrm{~N}-20 \mathrm{P}-20 \mathrm{~K}$ : $10 \%$ urea $+6 \%$ $\mathrm{NO} 3+4 \% \mathrm{NH} 4+20 \% \mathrm{P}_{2} \mathrm{O}_{5}+20 \% \mathrm{~K}_{2} \mathrm{O}$, a product of Haifa Chemicals). Ten liters of fertilizer solution were sprayed evenly on each treated plot. Fertilizer was applied in winter, once each year, after the first effective rainfall.

Five replications of each of the 4 shrub removal treatments were randomly assigned to 'no fertilization' treatment; 5 additional replications of the same treatments were also randomly selected and assigned to fertilization treatment.

\section{Vegetation Monitoring}

Four permanent transects (totalling 20 m) were established, at equal intervals, across each experimental plot. Presence or absence of vegetation components $(S$. spinosum, perennial grasses and annual grasses) was recorded every $10 \mathrm{~cm}$ along the transect (200 points/plot) using a wirepin. The ratio between number of hits per life-form $(Z)$ and total number of points $(\mathrm{Z} / 200 * 100)$, served as a measure of aerial cover (\%). The first vegetation monitoring was conducted before treatment application (autumn 1989), and then in the following 2 spring seasons (1991, 1992).

Yield (biomass) of herbaceous vegetation (including annual and perennial, grasses and forbs together) was determined each year in the peak growing season (early April). Ten, 25 x $25 \mathrm{~cm}$ quadrats were distributed at random in each plot, and all herbaceous vegetation within each quadrat was clipped. Samples were dried at $80^{\circ} \mathrm{C}$ for 3 days and then weighed. Herbage yield $\left(\mathrm{g} \mathrm{m}^{-2}\right)$ from each plot was calculated as the average of the samples.

\section{Data Analysis}

Data were analyzed by SAS-PC software (SAS 1988). Treatment and interaction effects were tested by Two-Way Analysis of Variance (ANOVA). Data on plant cover for this procedure were arcsin of square root transformed. If there was no

Table 1. Two-Way ANOVA of the effect of shrub removal and fertilization and their interaction on herbaceous biomass and relative abundance of vegetative components.

\begin{tabular}{|c|c|c|c|c|c|c|c|c|c|}
\hline & \multicolumn{3}{|c|}{ Model } & \multicolumn{2}{|c|}{ Shrub Removal (ShR) } & \multicolumn{2}{|c|}{ Fertilization $(\mathrm{F})$} & \multicolumn{2}{|c|}{$(\mathrm{ShR}) *(\mathrm{~F})$} \\
\hline & $(\mathrm{F}(\mathrm{df}=7)$ & $\mathrm{P}$ & $\mathrm{R} 2$ & $F(d f=3)$ & $\mathrm{P}$ & $\mathrm{F}(\mathrm{df}=3)$ & $\mathrm{P}$ & $\mathrm{F}(\mathrm{Df}=3)$ & $\mathrm{P}$ \\
\hline \multicolumn{10}{|l|}{1991} \\
\hline Herbage Biomass & 2.49 & 0.366 & 0.35 & 3.98 & 0.0162 & 68.63 & 0.0582 & 0.55 & 0.6535 \\
\hline SRPT Cover & 29.72 & 0.0001 & 0.87 & 65.85 & 0.0001 & 0.6555 & 0.2 & 3.43 & 0.0286 \\
\hline PRGR Cover & 7.75 & 0.0001 & 0.63 & 16.46 & 0.0001 & 0.31 & 0.5819 & 1.53 & 0.2253 \\
\hline ANGR Cover & 1.68 & 0.1494 & 0.27 & 0.78 & 0.5165 & 0.61 & 0.4405 & 2.94 & 0.0479 \\
\hline \multicolumn{10}{|l|}{1992} \\
\hline Herbage Biomass & 7.34 & 0.0001 & 0.62 & 6.6 & 0.013 & 24.44 & 0.0001 & 2.38 & 0.0878 \\
\hline SRPT Cover & 8.84 & 0.0001 & 0.66 & 17.46 & 0.0001 & 0.89 & 0.3512 & 2.88 & 0.0509 \\
\hline PRGR Cover & 4.85 & 0.008 & 0.51 & 10.18 & 0.0001 & 0.01 & 0.9301 & 1.14 & 0.3496 \\
\hline ANGR Cover & 1.84 & 0.1137 & 0.29 & 3.18 & 0.0373 & 0.61 & 0.4402 & 0.91 & 0.4461 \\
\hline
\end{tabular}

SRPT $=$ Sarcopoterium spinosum

PRGR $=$ Perennial grasses

ANGR $=$ Annual grasses 

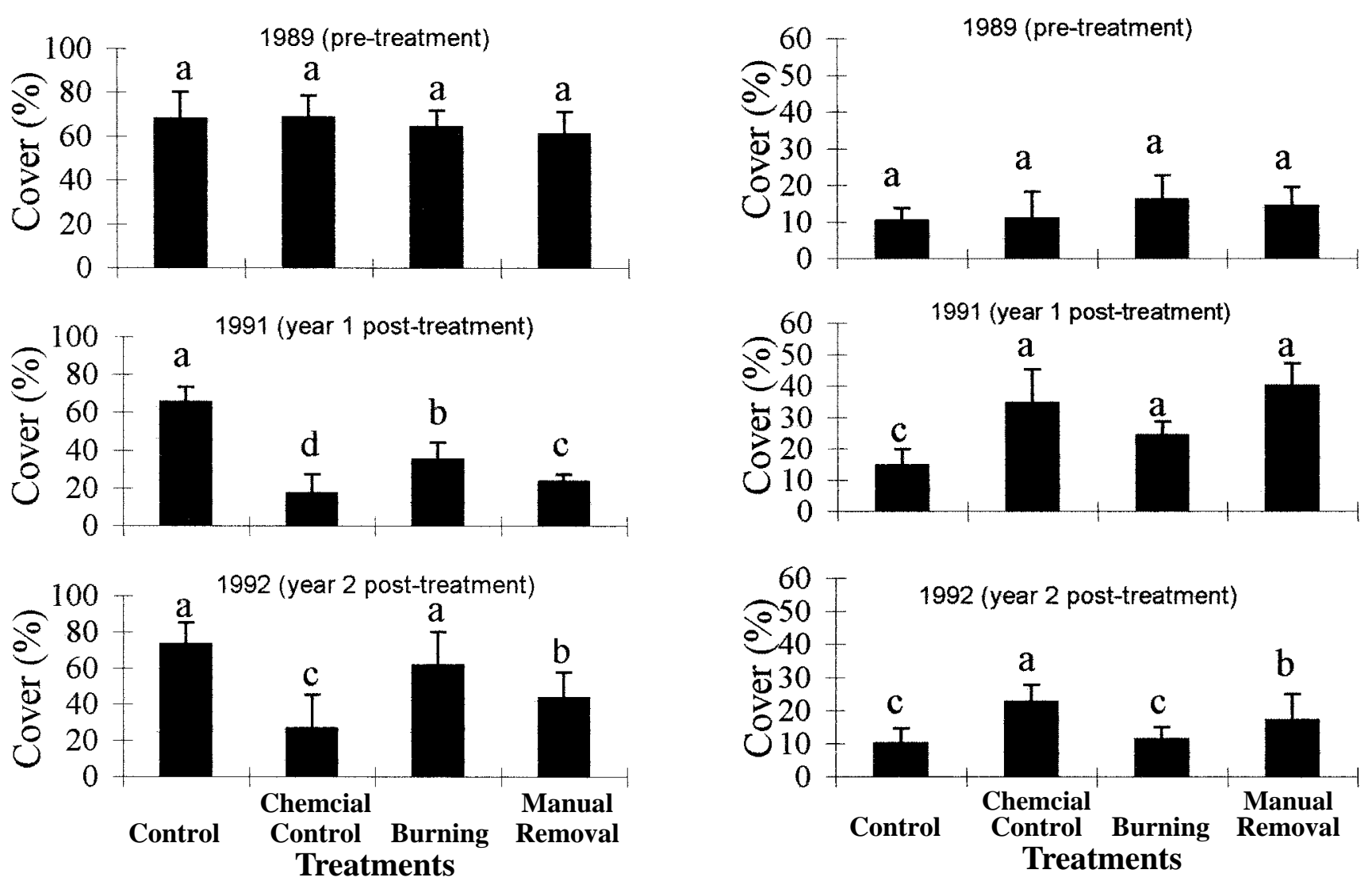

Fig. 1. Treatment means $( \pm$ SE) for prickly burnet (Sarcopoterium spinosum) cover (\%). All treatment means within the same year followed by a different letter are statistically different at the 5\% level.

Fig. 2. Treatment means $( \pm \mathrm{SE})$ for the cover of perennial grasses. All treatment means within the same year followed by a different letter are statistically different at the $5 \%$ level.

effect of fertilization treatments, vegetation data of fertilized and unfertilized plots of each shrub removal treatment were combined, thus increasing sample size. All differences discussed are statistically significant at the $5 \%$ level unless otherwise indicated.

Effects of shrub removal treatments and fertilization on cover of all vegetation components were also analyzed by canonical analysis (CANOCO). This program was developed specially to present multiple species' response to environmental factors (Ter Braak and Prentice 1990). Canonical Correspondence Analysis (CCA) was applied to arcsin transformed percentage cover $(\%+1)$ data using the various treatments as environmental variables. The Monte Carlo test was used to test the hypothesis that distribution of vegetation components among different treatments along the first ordination axis was random.

\section{Results and Discussion}

All vegetation parameters, except annual grasses, were increased by both shrub removal and fertilization (Table 1). This outcome combines the impact of shrub removal on both biomass and cover, and the fertilization effect on biomass. The interaction of shrub removal $X$ fertilization was significant on S. spinosum in both years and on annual grasses in 1992. The fact there was no effect of fertilization on plant cover allowed us to combine all data (with and without fertilization) for further analyses.

There were no differences in prickly burnet cover among plots prior to treatments (Fig. 1. 1989). Immediately after the manual removal and burning treatment (January 1990), prickly burnet cover was nearly zero. One year post-treatment (spring 1991), prickly burnet cover in the control plots had not changed $(65.3 \%)$, whereas burning, manual removal, and herbicide treatments, reduced its cover to
$34.9 \%, 23.4 \%$ and $17.2 \%$, respectively. Two years after treatment (spring 1992) cover in burned plots had already recovered, almost reaching the level of the control plots $(61.2 \%)$. In manual-removal plots, prickly burnet cover increased to $43.3 \%$, whereas in herbicide plots, there was a relatively small change in cover, increasing only to $25.7 \%$.

There were no differences in perennial grass cover among plots prior to treatment (Fig. 2. 1989). Cover of perennial grasses in 1991, in all treated plots, increased when compared with untreated control plots $(14.5 \%)$. In manual-removal, herbicide and burned plots, perennial grass cover was $40 \%, 34.5 \%$ and $24.2 \%$, respectively. One year later (spring 1992) there was no difference in cover of perennial grasses between burned and control plots $(\sim 10 \%)$. However, in manual-removal and herbicide treatments, perennial grass cover was still greater than in the control (Fig. 2).

In contrast to prickly burnet and perennial grass cover, annual grass cover was much lower and not homogeneous among 

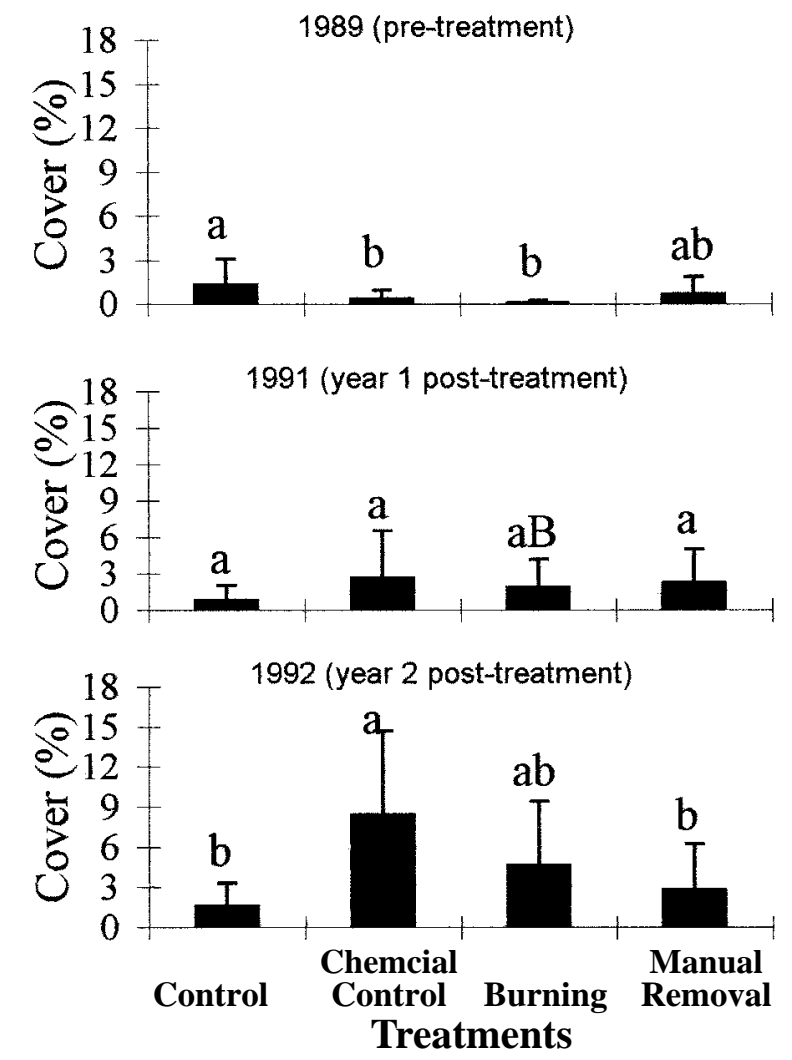

Fig. 3. Treatment means $( \pm \mathrm{SE})$ for the cover of annual vegetation. All treatment means within the same year followed by a different letter are statistically different at the $5 \%$ level.

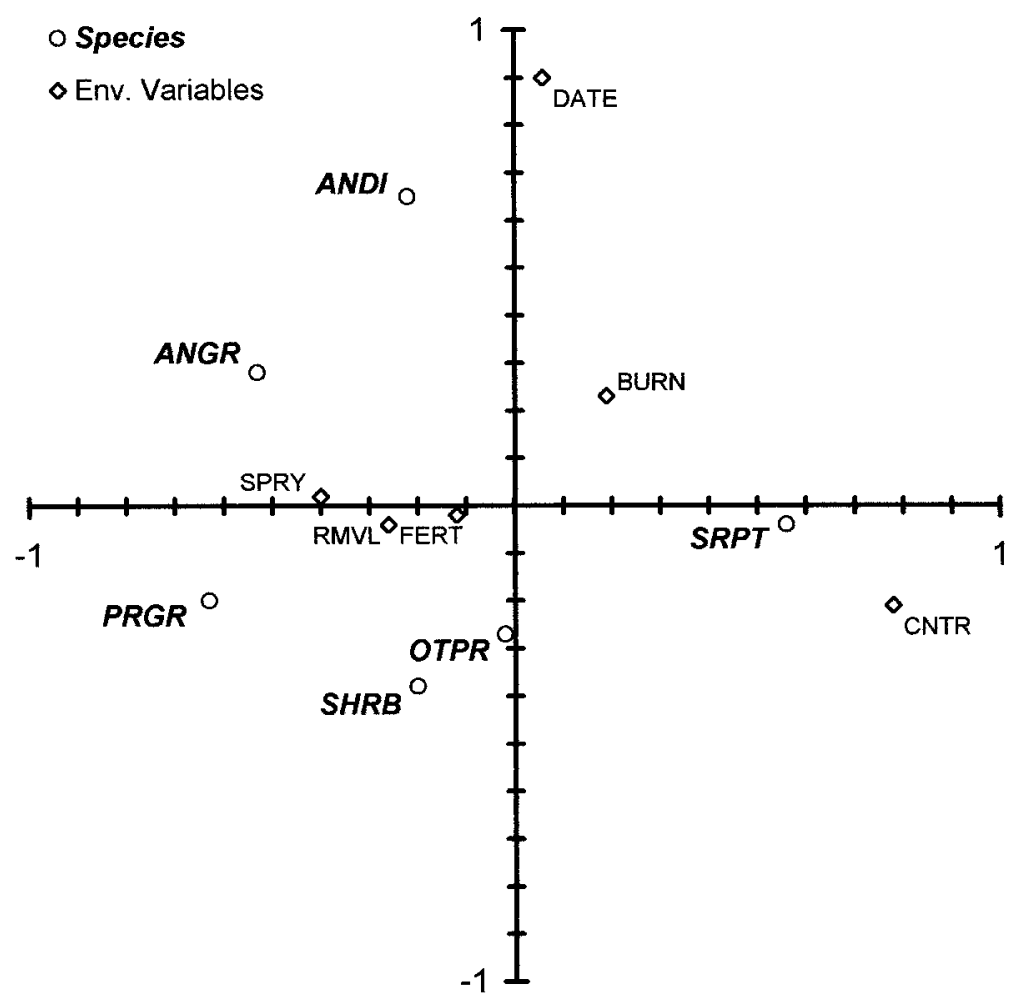

Fig. 4. An ordination plot of the treatment effects on the cover of all vegetation components. the experimental plots prior to treatment (Fig. 3). Cover of annuals was greater in control plots probably because of the spatial variability and low absolute values of cover in undisturbed situation. One year after treatment, cover of annuals in treated plots was somewhat greater $(\mathrm{p} \cong 0.52)$ than that of the control. After 2 years this trend was maintained and even became more pronounced. In the burned, manualremoval and herbicide treated, cover was $4.6 \%, 2.8 \%$, and $8.4 \%$, respectively compared to $1.6 \%$ in the control plots.

Some treatments-herbicide (SPRY), manual-removal (RMVL) and fertilization (FERT)-affected cover of S. spinosum negatively and therefore are located far from the control (CNTR) along the horizontal axis of the canonical ordination plot (Fig. 4). The burning treatment (BURN), on the other hand, is relatively close to the control. Time since treatment (DATE) also had a limited impact on the vegetation. The same treatments, however, increased annual and perennial herbaceous species (annual grasses and perennial grasses). The Eigen value of the first axis is 0.03; a Monte Carlo test showed that distribution of species along the first axis of the ordination plot was not random.

Total herbaceous biomass in 1991 was increased by shrub removal treatments, but only partly by fertilization $(\mathrm{p} \cong 0.06$ ); in 1992 it was increased by both removal and fertilization (Table 1). In 1991 herbicide and removal treatments produced higher biomass yields than the control, but there was no fertilization effect (Fig. 5). In 1992 fertilization caused an increase in herbaceous biomass in all experimental plots as compared to either unfertilized (except in herbicide treatment) or untreated plots (Fig. 5).

Productivity of Mediterranean rangelands is limited by a relatively high cover of woody vegetation (Seligman 1996) as well as by a low level of essential minerals (N or P) in the soil (Osman et al. 1991, Henkin et al. 1996). This study examined the effects of manipulating these 2 driving factors (shrub cover and soil mineral content) on the structure and productivity of the herbaceous vegetation community growing on chalky habitats.

All shrub removal treatments applied in this study generated a drastic reduction of prickly burnet cover in the experimental plots, immediately after treatment. However, treatment-related differences were recorded in recovery rate of prickly burnet. Spraying with 2-4D was the most efficient treatment and 2 years after treatment, prickly burnet cover reached only 


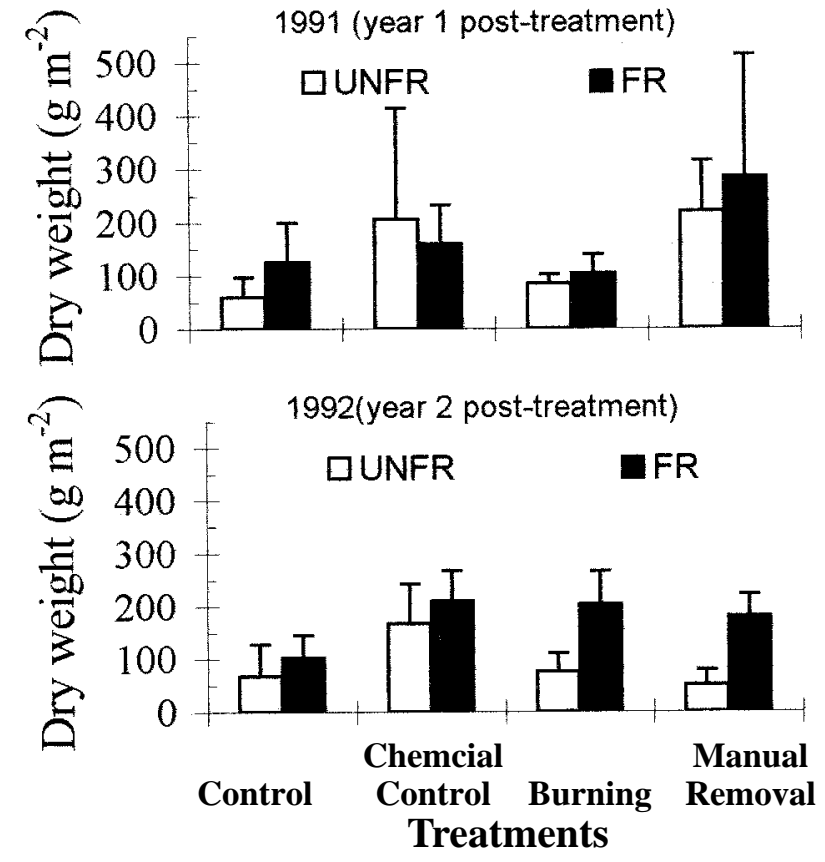

Fig. 5. The effect of fertilization on the biomass (means \pm SE) of herbaceous vegetation for control, herbicide, burning and shrub removal treatments.

$40 \%$ of the initial value. Manual removal was moderately effective, reaching $60 \%$ of the original value after 2 years. Controlled burning decreased shrub cover for a very limited period of time, but prickly burnet regained almost all its original cover within 2 years from burning. In Greece prickly burnet returned to pre-burning biomass level within 4.5-7.5 years (Papanastasis 1980). In Israel, under different environmental conditions (terra-rossa soil on hard limestone), prickly burnet cover increased to its original cover after burning at a slower rate (less than 6 years - Henkin et al. 1998).

Aggressive regrowth of prickly burnet is mostly a result of intensive resprouting from underground adventive basal buds (Litav and Orshan 1971, Papanastasis 1980). However, its rapid recovery after burning is, most certainly, a consequence of a combined effect of the intensive resprouting and a fire-stimulated germination (ArianoutsouFaraggitaki 1984). Germination rate of prickly burnet was 10 times higher on burned sites than on unburned plots (Arianoutsou and Margaris 1981).

The herbicide treatment had a lethal effect on prickly burnet shrubs and inhibited resprouting in comparison to the control. It may also have reduced germination by the shading effect of the dead canopy on light-controlled germination (Litav et al. 1963). In a similar experiment, under different environmental conditions, herbi- cides reduced prickly burnet cover drastically and after 6 years it reached not more than one-third of its original cover (Henkin et al. 1998).

Fertilization had no effect on regrowth of prickly burnet, indicating that mineral nutrition was not a limiting factor for shrub development in the studied ecosystem. This seems to contradict statements that the Mediterranean ecosystem is limited by nutrients (Kruger 1987). However, fertilizer application did increase herbage yield, especially in the second year. The Eocene rendzina is much richer in available nutrients than the more widespread hard limestone habitats.

Prickly burnet removal made available new sites and resources for other vegetation components. Consequently, abundance (cover) of perennial grasses increased when prickly burnet cover decreased. The most effective treatments in removing prickly burnet (manual removal and herbicide spraying) also stimulated most strongly the growth of perennial grasses. Fast recovery of prickly burnet from removal, reduced the relative increase of perennial grasses (1992 vs 1991).

Absolute cover of annuals in prickly burnet dwarf shrub formation is very low, probably due to competition by taller plant life-forms (shrubs and perennial grasses) under stressful conditions (low levels of soil moisture). Annuals did not respond as quickly as perennial grasses to removal of prickly burnet, and the main increase in their cover was during the second year. This observation is related, most probably, to seed-bank limitations (Looney and Gibson 1995), thus explaining the time lag of 1 year before annuals became more abundant. Here too, a higher abundance of annuals was facilitated by a lower shrub cover as a result of herbicide spraying.

Our observations do not support the hypothesis that the applied treatments can easily change the community structure and create a new balance among vegetation components. The most prominent conclusion of this study is that, despite drastic interventions (fire, manual-removal and herbicide treatments), the prickly burnet community recovers quickly and returns to its original structure within a few years. In other words, it creates a very resilient formation (Fox and Fox 1988). In particular this is the case on fertile, soft chalk habitats, where prickly burnet establishes easily and rapidly from seeds and grows vigorously. On terra-rossa overlying hard limestone, growth of prickly burnet is much less vigorous, and recovery after burning is slower (Henkin et al. 1998).

Our results support the notion that the most efficient option for suppressing encroaching shrubs is to combine treatments (Scifres 1987), some of them drastic. Such a combination should include a tool to remove mature shrubs (e.g. mechanical treatment or fire), a suppressing tool to obviate recovery of removed shrubs (selective herbicide spraying), and a grass-stimulating tool (fertilization or sludge application) that will make the herbaceous stand denser, thus helping it to compete with prickly burnet seedlings for resources (light, water). To maximize the outcome of such combined management practice, shrub removal should be conducted in autumn (before the rains; Papanastasis 1980), selective spraying (anti-dicot) - in the following late spring or summer, and fertilization-after the first rains of the second year. Nevertheless, the cost of such a combined shrub control procedure may be excessive where rangelands are degraded by heavy grazing and/or erosion.

Our results also explain why grasslands are not common in the east Mediterranean (Seligman 1996) and why range improvement in this environment is expensive and frustrating. However, rapid shrub encroachment and an increasing fire hazard make attempts to control shrub cover in the Mediterranean ecosystems an important and relevant management challenge (Perevolotsky and Seligman 1998). 


\section{Literature Cited}

Arianoutsou-Faraggitaki, M. 1984. Post-fire successional recovery of a phryganic (East Mediterranean) ecosystem. Acta Oecol./ Oecol. Plant. 5:387-394.

Arianoutsou, M. and N.S. Margaris. 1981. Early stages of regeneration after fire in a phryganic ecosystem (east Mediterranean). I. Regeneration by seed germination. Biol.Ecol. Médit. 8:119-128.

Baruch, U. 1986. The late Holocene vegetational history of Lake Kinneret (Sea of Galilee), Israel. Paléorient 12/2:37-48.

Dan, J., D.H. Yaalon, H. Koyumdjisky, and Z. Raz. 1962. The soils and soil association map of Israel. Israel Ministry of Agr. and The Hebrew Univ. of Jerusalem, Israel.

Fox, B.J. and M.D. Fox. 1988. Resilience of animal and plant communities to human disturbance. p. 39-64. In: B. Dell, A.J.M. Hopkins and B.B. Lamont, (eds.). Resilience in Mediterranean-type Ecosystems. Dr. Junk, Dordrecht, the Netherlands

Gutman, M., Z. Henkin, I. Noy-Meir, Z. Holzer, and N. Seligman. 1990. Plant and animal response to beef cattle grazing in a Mediterranean oak scrub forest in Israel Proc. 6th Meeting of the FAO European Subnetwork on Mediterranean Pastures and Fodder Crops. Oct. 17-19, 1990, Bari, Italy.

Henkin, Z., I. Noy-Meir, U. Kafkafi, and N. Seligman. 1996. Phosphate fertilization primes production of rangeland on brown rendzina soils in the Galilee, Israel. Agr., Ecosyst. \& Environ. 59:43-53.
Henkin, Z., N. Seligman, I. Noy-Meir, U. Kafkafi, and M. Gutman. 1998. Rehabilitation of Mediterranean dwarf-shrub rangeland with herbicides, fertilizers, and fire. J. Range Manage. 51:193-199.

Kruger, F.J. 1987. Responses of plants to nutrient supply in Mediterranean-type ecosystems, p. 415-427. In: J.D. Tenhunen, (eds.). Plant Response to Stress. SpringerVerlag, Berlin.

Litav, M. and G. Orshan. 1971. Biological flora of Israel. 1. Sarcopoterium spinosum (L.) sp. Isr. J. Bot. 20:48-64.

Litav, M., B.H. Kupernik, and G. Orshan. 1963. The role of competition as a factor in determining the distribution of dwarf shrub communities in the Mediterranean territory of Israel. J. Ecol. 51:467-480.

Looney, P.B. and D.J. Gibson. 1995. The relationship between soil seed bank and above-ground vegetation of a coastal barrier island. J. Veg. Sci. 6:825-836.

Naveh, Z. and J. Dan. 1973. The human degradation of Mediterranean landscapes in Israel, p. 373-390. In: F. Di Castri, and H.A. Mooney, (eds.), Mediterranean-type Ecosystems: Origin and Structure. Ecol. Studies, Vol. 7. Springer-Verlag, Berlin, Germany.

Osman, A.E., P.S. Cocks, L. Russi, and M.A. Pagnotta. 1991 Response of Mediterranean grassland to phosphate and stocking rates: biomass production and botanical composition. J. Agr. Sci., Camb. 116:37-46.
Papanastasis, V.P. 1980. Effects of season and frequency of burning on a phryganic rangeland in Greece. J. Range Manage. 33:251-255.

Passera, C.B., O. Borsetto, R.J. Candia, and C.R. Stasi. 1992. Shrub control and seedling influence on grazing capacity in Argentina. J. Range Manage. 45:480-482.

Perevolotsky A. and N.G. Seligman. 1998. Degradation of Mediterranean rangeland ecosystems by grazing: inversion of a paradigm. BioSci. 48:1007-1017.

SAS 1988. SAS/Stat User's Guide: Statistics. SAS Institute Inc., Cary, N.C., USA.

Scifres, C.J. 1987. Decision-analysis approach to brush management planning: ramifications for integrated range resources management. J. Range Manage. 40:482-490.

Seligman, N.G. 1996. Management of Mediterranean grasslands. p. 359-391. In: J. Hodgson and A.W. Illius, (eds.). The Ecology and Management of Grazing. CAB International, Wallingford, UK.

Seligman, N.G. and J. Katzir. 1965. Control of prickly burnet (Poterium spinosum L.) in rangelands of the southern Judean foothill region. J. Range Manage. 18:343-334.

Ter Braak, C.J.F. and I.C. Prentice. 1990. A theory of gradient analysis. Advances in Ecological Research, Vol. 18. Academic Press, London, UK.

Zohary, M. 1962. Plant Life in Palestine (Israel and Jordan). Ronald Press, New York, N.Y. 